Section Editor

Mitchell S.V. Elkind, MD, MS

Richard A. Rison, MD, FAANEM

Regina Berkovich, MD, $\mathrm{PhD}$

Address correspondence and reprint requests to Dr. Richard A. Rison, Neurology Consultants Medical Group, 12291 E. Washington Blvd., Suite 303, Whittier, CA 90606 rison@usc.edu

\section{Teaching NeuroImages: \\ Hiccoughs and vomiting in neuromyelitis optica}

Figure $2 \quad$ MRI of the orbits and optic chiasm

Figure $1 \quad$ MRI of the cervical spine

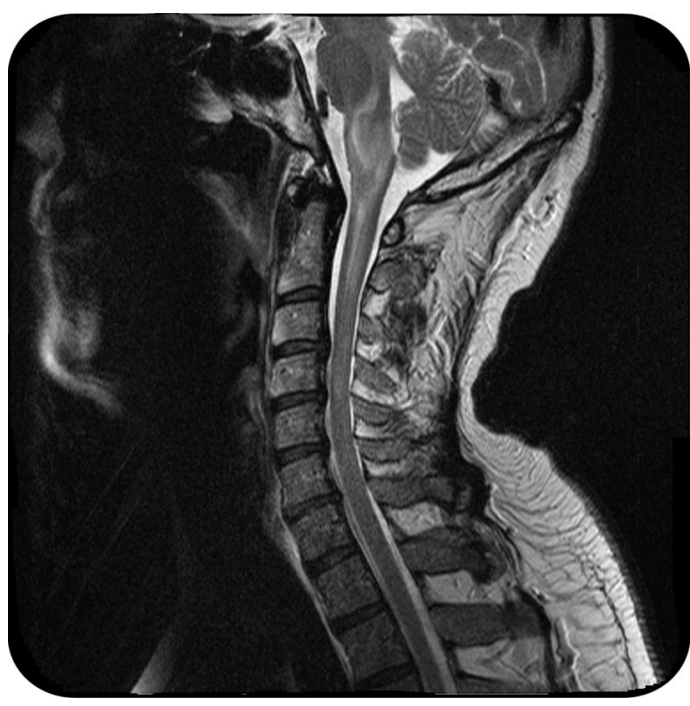

T2 sagittal noncontrast MRI of the cervical spine demonstrating an abnormal signal beginning at the pontomedullary junction and extending through the cervical cord. On postcontrast imaging (not shown), there was intense enhancement at the medullary level.

A 50-year-old man with a history of recurrent optic neuritis and past thoracic transverse myelitis presented with rapidly progressive quadriparesis, urinary incontinence, dyspnea, dysphagia, dysarthria, intractable hiccoughs, nausea, vomiting, and blurry vision. MRI revealed prominent demyelinating findings at the upper cervical cord and pontomedullary junction (figure 1) and optic chiasm (figure 2). The patient's serum was positive for neuromyelitis optica

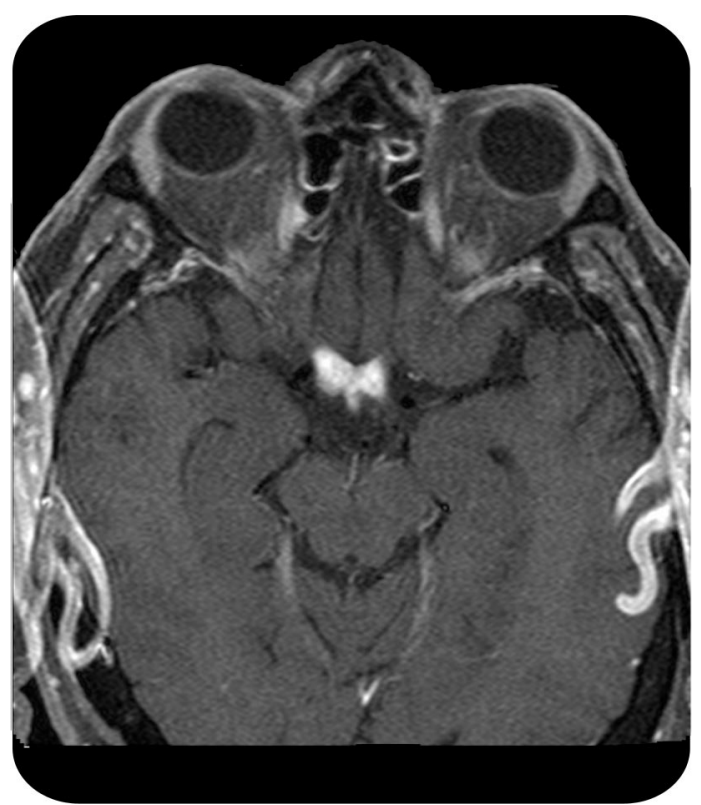

T1 postcontrast MRI of the orbits demonstrating considerable enlargement with abnormal signal and dramatic enlargement of the optic chiasm.

(NMO)-immunoglobulin G and he responded well to plasmapheresis.

In addition to optic nerve-chiasmal and spinal cord pathology, NMO has been reported to have aggressive brainstem involvement resulting in intractable hiccoughs with persistent nausea and vomiting. ${ }^{1}$

\section{REFERENCE}

1. Wingerchuk DM. Diagnosis and treatment of neuromyelitis optica. Neurologist 2007;13:2-11.

From the Los Angeles County Medical Center (R.A.R.) and USC MS Comprehensive Care (R.B.), University of Southern California, Keck School of Medicine, Los Angeles; and Presbyterian Intercommunity Hospital Stroke Center (R.A.R.), Presbyterian Intercommunity Hospital, Whittier, CA. Disclosure: Dr. Rison serves as an Associate Neurology Editor for the Journal of Medical Case Reports, Case Reports in Neurology, and Cases Journal. Dr. Berkovich serves on speakers' bureaus for and has received funding for travel and speaker honoraria from Bayer Schering Pharma, Biogen Idec, Teva Pharmaceutical Industries Ltd., Questcor Pharmaceuticals, Inc., and Acorda Therapeutics Inc.; and receives research support from Questcor Pharmaceuticals, Inc., Bayer Schering Pharma, Biogen Idec, and the National Multiple Sclerosis Society. 


\title{
Neurology
}

\author{
Teaching NeuroImages: Hiccoughs and vomiting in neuromyelitis optica \\ Richard A. Rison and Regina Berkovich \\ Neurology 2010;75; 70 \\ DOI 10.1212/WNL.0b013e3181f962e9
}

This information is current as of October 25, 2010

\section{Updated Information \& Services}

References

Subspecialty Collections

Permissions \& Licensing

Reprints including high resolution figures, can be found at: http://n.neurology.org/content/75/17/e70.full

This article cites 1 articles, 0 of which you can access for free at: http://n.neurology.org/content/75/17/e70.full\#ref-list-1

This article, along with others on similar topics, appears in the following collection(s):

All Clinical Neurology

http://n.neurology.org/cgi/collection/all_clinical_neurology Devic's syndrome

http://n.neurology.org/cgi/collection/devics_syndrome Optic neuritis; see Neuro-ophthalmology/Optic Nerve http://n.neurology.org/cgi/collection/optic_neuritis

Transverse myelitis

http://n.neurology.org/cgi/collection/transverse_myelitis

Information about reproducing this article in parts (figures,tables) or in its entirety can be found online at:

http://www.neurology.org/about/about_the_journal\#permissions

Information about ordering reprints can be found online:

http://n.neurology.org/subscribers/advertise

Neurology ${ }^{\circledR}$ is the official journal of the American Academy of Neurology. Published continuously since 1951, it is now a weekly with 48 issues per year. Copyright Copyright (? 2010 by AAN Enterprises, Inc.. All rights reserved. Print ISSN: 0028-3878. Online ISSN: 1526-632X.

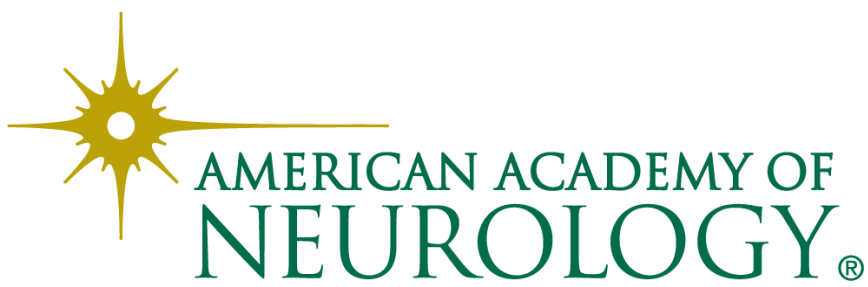

